Review

\title{
Enzymatic Biofuel Cells-Fabrication of Enzyme Electrodes
}

\author{
Eileen Hao Yu * and Keith Scott
}

School of Chemical Engineering and Advanced Materials, Newcastle University, Newcastle upon Tyne, NE1 7RU, UK; E-Mail: k.scott@ncl.ac.uk

* Author to whom correspondence should be addressed; E-Mail: eileen.yu@ncl.ac.uk; Tel.: +44-191-222-7243; Fax: +44-191-222-5292.

Received: 9 November 2009 / Accepted: 4 January 2010 / Published: 11 January 2010

\begin{abstract}
Enzyme based bioelectronics have attracted increasing interest in recent years because of their applications on biomedical research and healthcare. They also have broad applications in environmental monitoring, and as the power source for portable electronic devices. In this review, the technology developed for fabrication of enzyme electrodes has been described. Different enzyme immobilisation methods using layered structures with self-assembled monolayers (SAM) and entrapment of enzymes in polymer matrixes have been reviewed. The performances of enzymatic biofuel cells are summarised. Various approaches on further development to overcome the current challenges have been discussed. This innovative technology will have a major impact and benefit medical science and clinical research, healthcare management, energy production from renewable sources.
\end{abstract}

Keywords: enzymes; bioelectronics; biofuel cells; self-assembled monolayer; redox polymer; mediator; enzyme immobilisation

\section{Introduction}

Enzymes are known for their highly specific catalytic activities for bioreactions. The interest in developing enzyme based bioelectronics, i.e. fuel cells and sensors, has arisen due to the increasing number of implantable medical devices developed for the healthcare applications in the last decade. Many applications of the technology are proposed as biosensors for monitoring the changes in physiological substances, such as glucose sensing for diabetes patients [1,2], and in vivo biofuel cells 
as the power sources for implantable devices [3-5]. Figure 1 shows a schematic diagram of a biofuel cell working in blood vessel using glucose and dissolved oxygen as fuel and oxidant, respectively. Electrochemical glucose sensors are most successful commercial biosensor devices for point-of-care and personal use because of the simplicity, flexibility and low cost of electrochemical transduction instrumentation. Enzymes have been also used on environmental sensors to monitor some specific pollutants [6-8]. Portable electronic devices, such as laptops, mobile phones and mp3 players, are new areas to use enzymatic biofuel cells [9-11]. Sony has developed a biofuel cell using sugar as the fuel and enzymes as catalysts to power a Walkman ${ }^{\circledR}$ [12]. Enzymatic bioelectronics show promising applications in various areas.

Figure 1. Schematic diagram of an enzymatic biofuel cell working in blood.

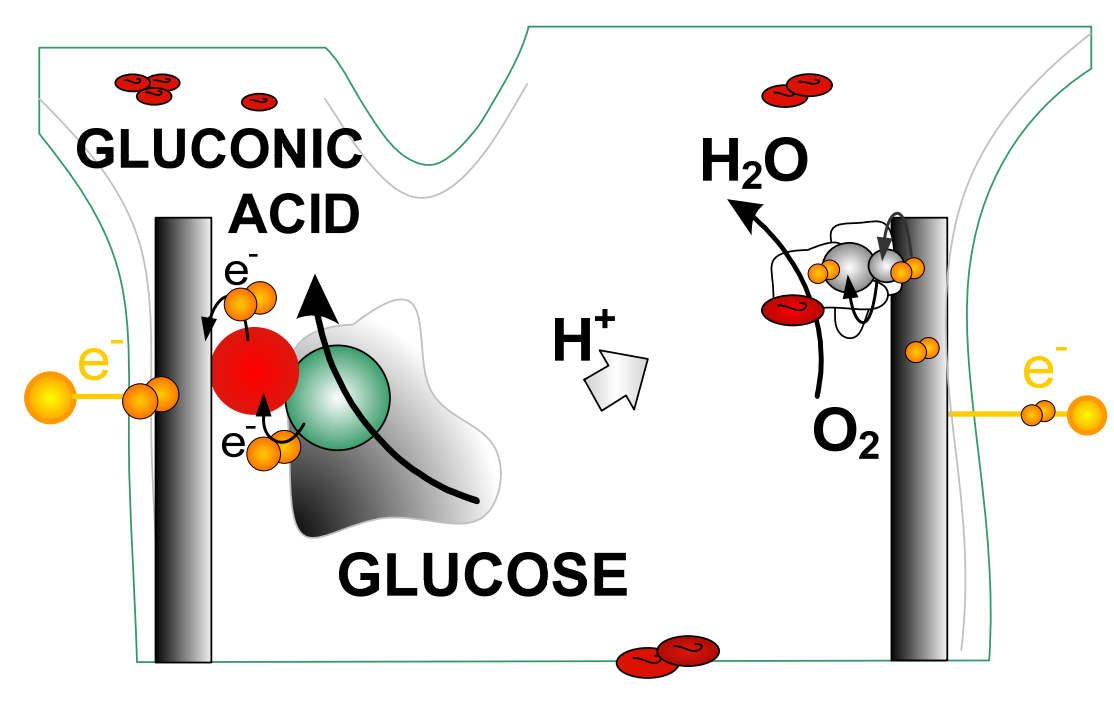

\begin{tabular}{|lll|}
\hline Enzyme & $\rightarrow$ & Blood Flow \\
Electrons & Mediator & Arterial Wall
\end{tabular}

Enzyme based fuel cells have been reported since the 1960s [13]. However, the development of enzymatic biofuel cells is still in its early days. Compared to conventional fuel cells, research on enzymatic biofuel cells are still in the fundamental research stage because of their low stability and power output. Electrodes biocatalytically modified with enzymes are the key for performance of biofuel cells. Research in the development of enzyme electrodes for biofuel cell and biosensor applications has been carried out extensively in recent years. Studies on understanding the reaction mechanisms of enzyme catalytic reactions [14,15], developing new biomaterials [16-20], on enzyme modification [21-27], enzyme immobilisation methods [28-34], and enzyme electrode structures [35] have been reported in the literature in an effort to improve the performance of enzyme electrodes. 


\section{Types of Biofuel Cells and Enzymes}

\subsection{Types of biofuel cells}

Based on the functions of the biocatalysts (enzymes), biofuel cells can be classified into two categories:

1. Product type. In this type of fuel cells enzymes are not involved in direct energy generation, and the energy generation is realised by a conversional fuel cell. Enzymes generate the fuel substrate for fuel cell by a biocatalytic transformation or metabolic process. There have been several studies that have demonstrated the use of hydrogenase to produce hydrogen from glucose for conventional hydrogen-oxygen fuel cells [36,37]. This type of biofuel cell is less common in enzymatic fuel cells.

2. Direct energy production type. In this type of biofuel cells, enzymes are directly involved in the bioreactions for energy production. Enzymes participate in the electron transfer chain between the fuel and the anode. On the anode, enzymes oxidise organic matters and produce electrons, and on the cathode, enzymes act as catalysts for oxidant reduction and accept electrons, the same principle as the conventional fuel cells. The performance of the fuel cell is mainly dependant on the enzyme activity. Most enzymatic fuel cells are this type. One of the main challenges for this type of fuel cells is to establish efficient electron transfer between enzymes and electrode supports.

\subsection{Types of enzymes based on electron transfer methods}

Redox enzymes can be divided into three groups (Figure 2) based on the location of enzyme active centres and methods of establishing electron transfer between enzymes and electrodes [38,39].

Figure 2. Three groups of enzymes based on location of enzyme active centre (A) Diffusive active centre (B) Active centre located on the periphery of the enzyme, (C) Strongly bound and deep buried redox centres [38,39].
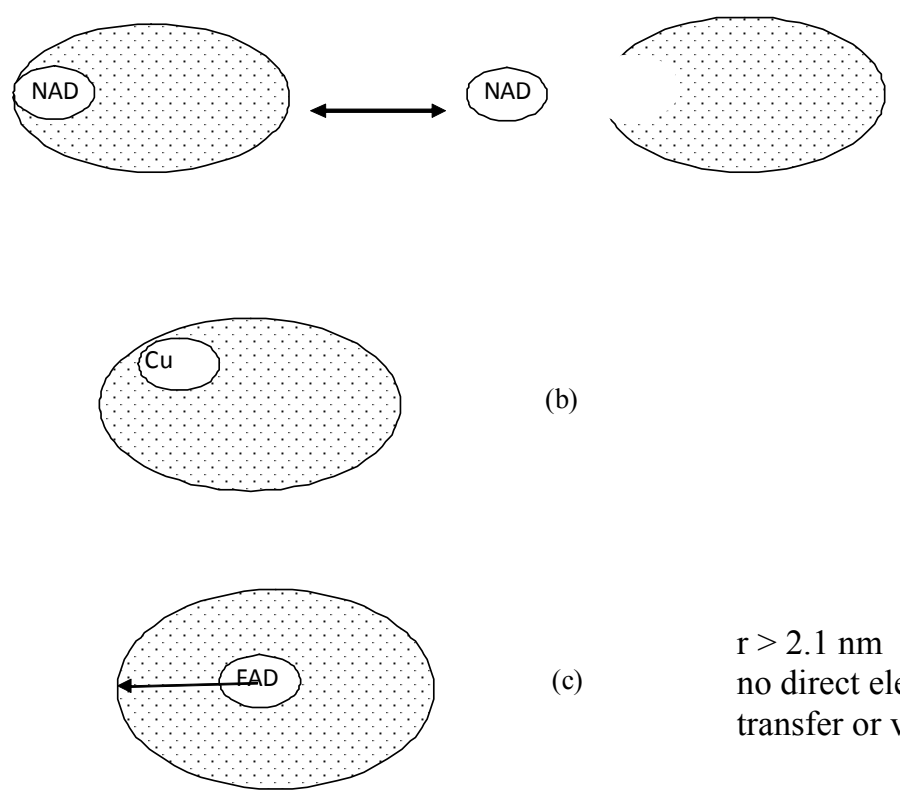
(1) Enzymes with nicotinamide adenine dinucleotide $\left(\mathrm{NADH} / \mathrm{NAD}^{+}\right.$) or nicotinamide adenine dinucleotide phosphate (NADPH/NADP ${ }^{+}$) redox centres, which are often weakly bound to the protein of the enzyme. Glucose dehydrogenase and alcohol dehydrogenase belong to this group.

(2) Enzymes in which at least part of the redox centre is conveniently located at or near the periphery of the protein shell. Peroxidases, laccase and other multi copper enzymes fall into this category. Peroxidases, such as horseradish peroxidises and cytochrome c peroxidise have been commonly used enzyme reactions and immunoassay.

(3) Enzymes with a strongly bound redox centre deeply bound in a protein or glycoprotein shell. Glucose oxidase is the most studied enzyme example of this type.

The first two groups are able to carry out direct electron transfer (DET) between the enzyme active centre and the electrode surface. For the second group, the orientation of enzyme on the electrode surface is the key affecting the activity of the enzyme. Enzymes in the third group are not able to have direct electron transfer between the active centres and electrodes due to the large distance, $>21 \mathrm{~A}$, between enzyme active centres and the electrode surface. In this case, for enzymes with the active centre deeply buried inside protein shell, direct electrical communication with electrodes can be established by using electron-transfer mediators. These artificial electron donor or acceptor molecules (in case of reductive or oxidative enzymes, respectively), can be accepted by many redox-enzymes in place of their natural oxidants or reductants. They have a wide range of structures, and hence properties, including a range of redox potentials. Figure 3 demonstrates the work principle of mediated electron transfer (MET) in enzymatic biofuel cells. It is clear that the performance of an enzymatic biofuel cell is largely dependent on the properties and activities of enzyme and mediator molecules.

Figure 3. Schematic diagram of work principle for mediated electron transfer in enzymatic biofuel cells.

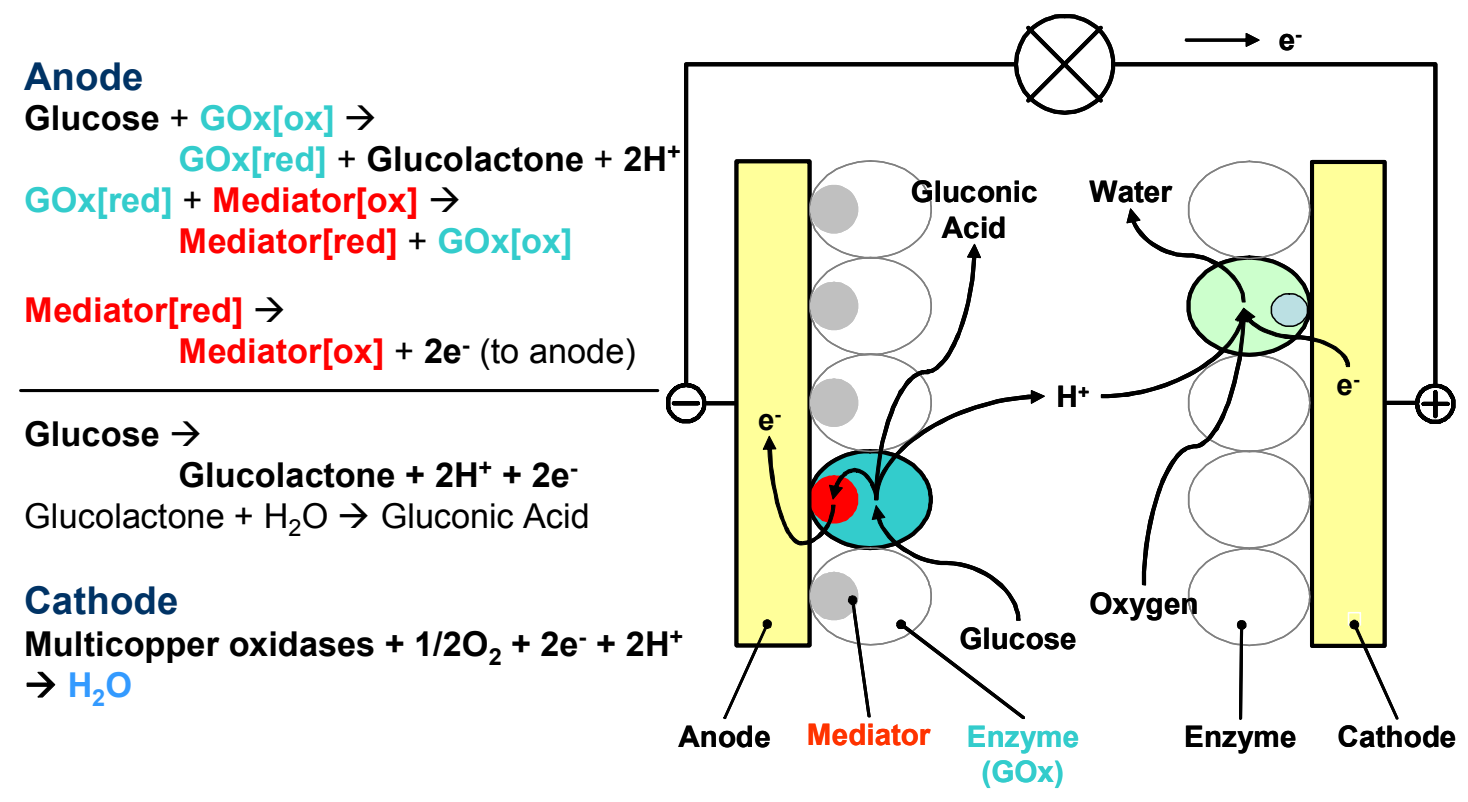

Mediators act as the electron transfer relay are based on a diffusional mechanism. Diffusional penetration of the oxidised or reduced relay into the protein can shorten the electron transfer distance between the enzyme active centre and electrode [40]. Ferrocene derivatives are the one of the most 
commonly used mediator for glucose oxidase. 'Wired' enzyme by covalently binding mediator molecule to enzyme to establish electron transfer was first developed by Degani and Heller [41]. Benzoquinone, hydroquinone and pyrroloquinoline quinine have been also reported as mediator for glucose oxidase.

\section{Fabrication of Enzyme Electrodes}

The proper functioning of an enzyme-based electrode relies on both the chemical and physical properties of the immobilised enzyme layer. Methods for immobilisation of enzymes can be divided into physical methods and chemical methods.

Physical methods include: (1) Gel entrapment. Enzymes were entrapped in a gel matrix, such as gelatine and polyacrylamide, as well as dialysis tubing [42]. (2) Adsorption. It is simple and no additional reagents are required but only weak bonding involved between enzymes and electrode surface. Enzyme electrodes using Ni-Fe hydrogenase and laccase for biofuel cell were prepared by adsorption of enzymes to graphite surface by Armstrong group in Oxford University [43]. Rapid electrocatalytic oxidation of hydrogen by hydrogenase that is completely unaffected by carbon monoxide was obtained. The reaction was only partially inhibited by oxygen.

Chemical methods are the main methods used for fabricating enzyme electrodes for biofuel cell applications. The methods include covalent immobilisation and immobilising enzyme in polymer matrix.

\subsection{Enzyme electrodes with layered structures}

Covalent immobilisation is the most irreversible and stable immobilisation technique. Most used materials are noble metals and carbon material. Enzyme electrodes with layered structure have developed based on covalent bindings. Enzymes immobilised on the electrode surface with selfassembled monolayer (SAM) or layer-by-layer structure binding mediator to transfer electrons from the site of fuel oxidation at the enzyme to the electrode surface.

Katz and Willner developed a method to establish direct electron transfer between the active centre of glucose oxidase and the electrode surface through a defined structured path by reconstitution of the enzyme with nitrospiropyran-modified and 2-aminoethyl modified flavin adenine dinucleotide, FAD, cofactor [23,24,44-47]. They produced a fuel cell using enzymes on both anode and cathode. The electrode substrate was gold. The anodic reactions (defined as below) were glucose oxidation using reconstituted glucose oxidase connecting with a monolayer of pyrroloquinoline quinine (PQQ) as the mediator, and the cathodic reaction was reduction of hydrogen peroxide by microperoxidase-11 (MP-11) [44]. The open circuit voltage of the cell was $c a .310 \mathrm{mV}$, and the maximum power density was around $160 \mu \mathrm{W} \mathrm{cm}^{-2}$.

$$
\begin{aligned}
& \text { Electrode-PQQ-FAD-GOx }+ \text { Glucose } \rightarrow \text { Electrode-PQQ-FADH }{ }_{2}-\mathrm{GOx}+\text { Gluconic acid } \\
& \text { Electrode-PQQ-FADH }{ }_{2}-\mathrm{GOx} \rightarrow \text { Electrode-PQQH } 2-\mathrm{FAD}-\mathrm{GOx} \\
& \text { Electrode-PQQH } 2 \text {-FAD-GOx } \rightarrow \text { Electrode-PQQ-FAD-GOx }+2 \mathrm{H}^{+}+2 \mathrm{e}^{-}
\end{aligned}
$$


Self-assembled monolayers are fabricated using thiol [48-50] group attaching to the gold electrode surface. SAMs with biospecific affinity for lactate dehydrogenase for the electroenzymatic oxidation of lactate were developed to produce enzymatic electrodes [51]. Gooding et al. [33], Sato et al. [52] and Dong and Li [53] have covalently immobilised redox proteins, enzymes, and phospholipids onto the self-assembled monolayers (SAMs) of 3-mercaptopropionic acid on a gold electrode surface. The electrochemical characteristics of self-assembled octadecanethiol monolayers on polycrystalline gold electrodes were studied simultaneously by means of cyclic voltammetry and by measuring the monolayer transient total capacitance as well as differential capacitance changes during the CV scan in the presence of various redox probes in bulk of the supporting electrolyte [54]. The results showed that the capacitance measurements are very sensitive to the changes in the structure of a monolayer in the course of redox reaction.

Enzyme electrodes with multi-layer structures have been studied with mono- and bienzymes for molecular recognition and generation of electrical signals [55-58]. Calvo et al. established enzyme electrodes using layer-by-layer supramolecular structures composed of alternate layers of negatively charged enzymes and cationic redox polyelectrolyte. Glucose oxidase (GOx), lactate oxidase (LOx) and soybean peroxidase (SBP) have been electrically wired to the underlying electrode by means of poly(allylamine) with $\left[\mathrm{Os}(\mathrm{bpy})_{2} \mathrm{ClPyCOH}\right]+$ covalently attached (PAA-Os) in organized structures with high spatial resolution. The concentration of redox mediator integrated into the multilayers, obtained from the voltammetric charge and an estimation of the layer thickness, exceeds by 100-fold the amount of deposited enzyme assessed by quartz crystal microbalance [59]. An electrode was fabricated by alternate layer-by-layer deposition of periodate-oxidized glucose oxidase (GOx) and poly(allylamine) (PAA) by Zhang et al. [32]. The covalent attachment process was followed and confirmed by electrochemical impedance spectroscopy (EIS). The gold electrodes modified with the GOx/PAA multilayers showed excellent electrocatalytical response to the oxidation of glucose with ferrocenemethanol as the mediator. From the analysis of voltammetric signals, the coverage of active enzyme on the electrode surface had a linear relationship with the number of GOx/PAA bilayers suggesting that the analytical performance can be tunable by controlling the number of attached bilayers.

\subsection{Enzyme electrodes with polymer matrix}

Although enzyme electrodes with layered structures have shown efficient electron transfer in various applications, there are some limitations. First, the amount of enzymes immobilised on the electrode is limited by electrode surface due to a monolayer covalent binding scheme. Second, the more molecular layers immobilised on the electrode surface, the more electric resistance would be introduced to the electrode, which in turn could affect the electronic response of the electrode. Also, the electrode activity will be influenced by the orientation of the enzymes and mediator molecules.

Conducting redox polymers can be a solution to overcome these limitations. Conducting polymers, such as polypyrrole and polyaniline, are very common to immobilise enzymes and fabricating enzyme electrodes. Polypyrrole (Ppy) is one of the most extensively used conducting polymers in the design of bioanalytical sensors. It has unique properties of prevention of some undesirable electrochemical interactions and facilitation of electron transfer from some redox enzymes [60]. Enzyme electrodes 
with polypyrrole are fabricated by electropolymerisation and enzymes are entrapped in the polymer as a dopant during the polymerisation process [22,61-66]. Polypyrrole can also be functionalised by adding cationic pendant groups, such as tris(bipyridyl)ruthenium(II) complex to the polymer films to introduce an electron relay [67]. A two-step method consists of the adsorption of an aqueous amphiphilic pyrrole monomer-enzyme mixture on an electrode surface followed by the electropolymerization of the adsorbed monomers was developed by Cosnire [68]. A new biotin derivative functionalized by an electropolymerizable pyrrole group has been synthesized. The electrooxidation of this biotin pyrrole has allowed the formation of biotinylated conducting polypyrrole films in organic electrolyte, which revealed an avidin-biotin-specific binding at the interface of polymer-solution. It provided an easy electrochemical approach for the reagentless immobilization of enzymes on electrode surfaces [69,70]. Figure 4 shows the SEM and AFM imagines of the polypyrrole film entrapped with ferrocene modified glucose oxidase [22].

Figure 4. Au electrode coated with a polypyrrole-FeFcGOx layer.
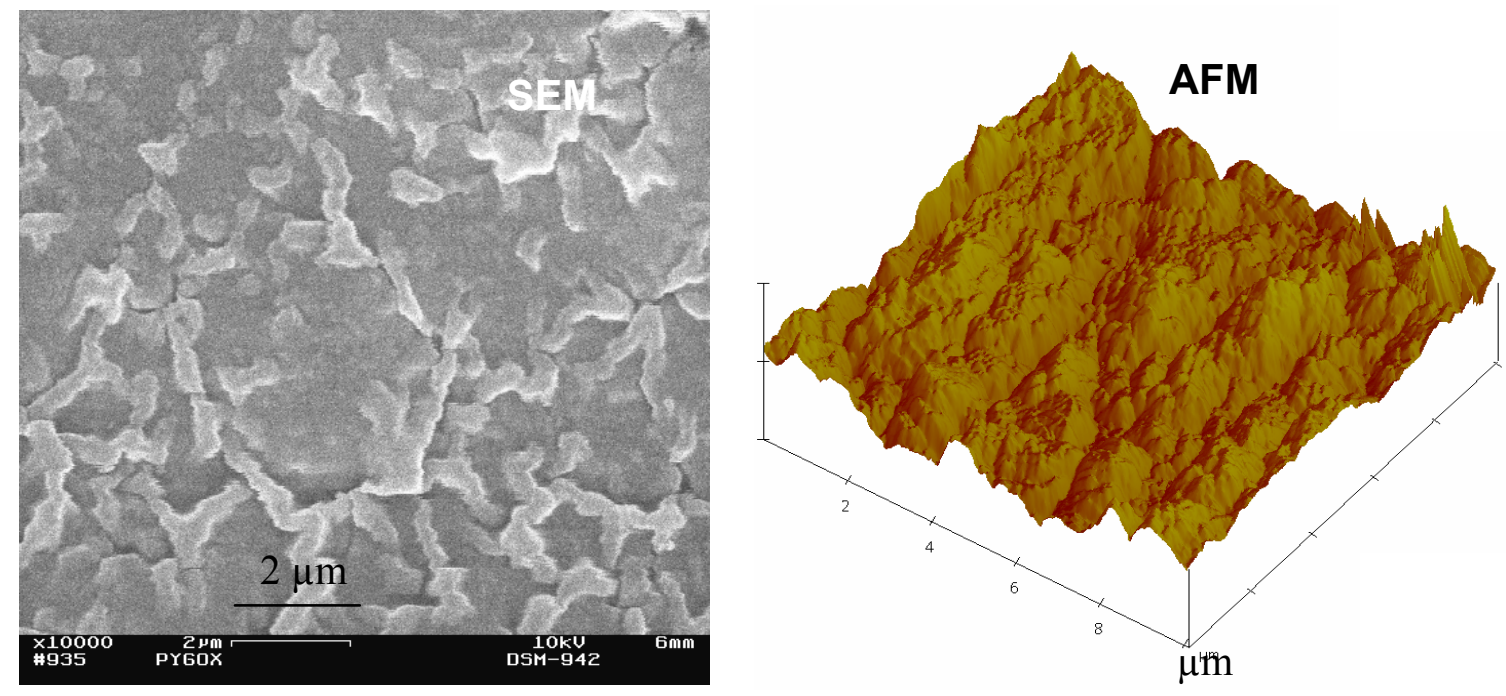

Polyaniline is another extensively used polymer for enzyme immobilisation. An enzyme-mediator-conducting polymer model using benzoquinone (Q)-polyaniline (Pani) system was established by Cooper and Hall. An enhanced current can be obtained on Pani [71]. Ratiman et al. [72] integrated polyaniline/poly(acrylic acid) films and redox enzymes for the study of the bioelectrocatalyzed oxidation of glucose or lactate. Improved selectivity and stability of glucose biosensor was obtained based on in situ electropolymerized polyaniline-polyacrylonitrile composite film [73]. A novel method was developed by the Willner's group to generate an integrated electrically contacted glucose dehydrogenase electrode by the surface reconstitution of the apo-enzyme on a pyrroloquinoline quinone (PQQ)-modified polyaniline [74]. The same group also developed an integrated enzyme-electrode where the glucose oxidase reveals direct electrical contact with the electrode using poly(aniline-aniline boronic acid) wires generated on ds-DNA templates [75].

In order to establish electron transfer between enzyme active centre and also provide the structure for enzyme immobilisation, polymer mediators have been developed and applied for the enzyme 
electrodes. Osmium based polymers are the most studied polymer in this context. The commercially available continuous glucose sensors have been using osmium based polymers to fabricate enzyme electrodes. The advantages of these polymers include wide redox potential windows from different derivatives for various redox reactions, fast electron transfer rate and good chemical stabilities.

In 1991, Heller's group developed a redox epoxy. The redox epoxy, designed for use in enzyme electrodes, was formed by reaching two water-soluble components (a poly(vinylpyridine) complex of $\mathrm{Os}(\mathrm{bpy})_{2} \mathrm{Cl}$ and a diepoxide) under near-physiological conditions. The binding simultaneously immobilizes the enzyme, glucose oxidase, and connects it electrically with the electrode. The catalytic "reaction layer" extends through the entire film [76,77]. Since then they have developed various Os polymer derivatives used for enzymatic oxidation and oxygen reduction reactions, as well as biofuel cells with these enzyme electrodes [2,78-87]. Micro enzyme electrodes were developed with $7 \mu \mathrm{m}$ diameter carbon fibres using poly[(vinylpyridine)Os(bipyridine) $\left.{ }_{2} \mathrm{Cl}\right]$ derivative-based redox hydrogels to immobilise glucose oxidase [88]. A miniaturised biofuel cell with this carbon fibre electrode configuration was developed [89]. The power density of this device was five times greater than the previous best biofuel cells. At $37{ }^{\circ} \mathrm{C}$, a power output of $600 \mathrm{nW}$ was obtained, which was enough to power small microelectronics.

For implantable applications, there is a concern about the leaching out of Os compounds for long term application because of their toxicity. Biocompatibility is another issue for implantable devices. Biopolymers based on phospholipid polymer mimicking the cell membrane were developed. Those polymers have good biocompatibility, and inhibit the adhesion and activation of blood cells, thus minimises blood coagulation when contacts blood $[17,19,90]$. Feasibility of introducing redox property to phospholipid polymers was investigated. By modification of polymer side chain, it is possible to use the biopolymers for enzyme electrodes for implantable applications [91]. A hydrophilic copolymer, poly(vinylferrocene-co-2-hydroxyethyl methacrylate) (poly(VFc-co-HEMA)), also a biopolymer, was prepared as a polymeric electron-transfer mediator for producing amperometric biosensors. The poly(VFc-co-HEMA) membrane is useful as an enzyme-immobilizing carrier matrix for fabricating glucose sensors as well as a polymeric electron-transfer mediator [92].

\section{Performance of Enzymatic Biofuel Cells}

One of the first enzymatic biofuel cells reported by Willner and Katz used a pyrroloquinoline quinone (PQQ) monolayer-functionalized-Au-electrode as the anode and a microperoxidase-11 (MP-11)-modified Au-electrode was used as the cathode [44]. The $\mathrm{H}_{2} \mathrm{O}_{2}$ was the cathodic oxidiser whereas the anodic fuel-substrate is 1,4-dihydronicotinamide adenine dinucleotide, NADH. The biofuel cell generates an open-circuit voltage of $c a .320 \mathrm{mV}$ and a short-circuit current density of $c a .30 \mu \mathrm{A} \mathrm{cm}^{-2}$. The maximum electrical power extracted from the cell is $8 \mu \mathrm{W}$ at an external load of $3 \mathrm{k} \Omega$.

Another biofuel cell developed by Willner and Katz was a novel glucose $/ \mathrm{O}_{2}$ biofuel cell without compartmentalisation between anode and cathode. The anode consisted of a surface reconstituted glucose oxidase monolayer, whereas the cathode was presented by the reconstituted cytochrome c/cytochrome oxidase couple. The system paves the way to tailoring implantable biofuel cells for generating electrical power [93]. 
Katz et al. applied the property of conductivity change for oxidation and reduction status of $\mathrm{Cu}$-poly(acrylic acid) polymer and developed an electroswitchable and tunable biofuel cell based on the biocatalyzed oxidation of glucose. By the cyclic electrochemical reduction and oxidation of the polymer films associated with the anode and cathode between the $\mathrm{Cu}-0$-poly(acrylic acid) and $\mathrm{Cu}^{2+}$ poly(acrylic acid) states, the biofuel cell performance is reversibly switched between "ON" and "OFF" states, respectively. The open-circuit voltage of the cell was $120 \mathrm{mV}$, and the short-circuit current density reached $550 \mu \mathrm{A} \mathrm{cm}{ }^{-2}$. The maximum extracted power from the cell is $4.3 \mu \mathrm{W}$ at an external loading resistance of $1 \mathrm{k} \Omega$. The slow reduction of the $\mathrm{Cu}^{2+}$ polymer films allows for the controlling of the content of conductive domains in the films and the tuning of the output power of the biofuel cell [94].

An enzyme-based biofuel cell with a $\mathrm{pH}$-switchable oxygen electrode, controlled by enzyme logic operations processing in situ biochemical input signals, was developed recently [95]. Two Boolean logic gates (AND/OR) were assembled from enzyme systems to process biochemical signals and to convert them logically into $\mathrm{pH}$-changes of the solution. The electrochemical activity of the modified electrode was switchable by alteration of the solution $\mathrm{pH}$ value. The electrode was electrochemically mute at $\mathrm{pH}>5.5$, and it was activated for the bioelectrocatalytic oxygen reduction at $\mathrm{pH}<4.5$. The sharp transition between the inactive and active states was used to control the electrode activity by external enzymatic systems operating as logic switches in the system.

The latest development from Mano et al. for a miniature, membrane-less glucose- $\mathrm{O}_{2}$ biofuel cell built with Os derivatives polymer mediators for glucose and bilirubin oxidase on anode and cathode, respectively was reported with a power density of $4.8 \mu \mathrm{W} \mathrm{mm}{ }^{-2}$ produced at the voltage of $0.60 \mathrm{~V}$ in a physiological buffer at $37.5^{\circ} \mathrm{C}$ [82].

Fruit juices, such as orange juice, grape juice and banana juice have been used as fuels for a membraneless biofuel cell. The cell was facile prepared based on glucose oxidase and laccase as anodic and cathodic catalyst, respectively, by using 1,1'-dicarboxyferrocene as the mediators of both anode and cathode. This research demonstrated the possibility of using easy access fruit juice to power portable electronics [9].

For implantable medical devices, nontoxic mediators for enzyme electrodes are essential. In Kyoto University, a biofuel cell was developed using vitamin K-3-modified poly-L-lysine (PLL-VK3) as the electron transfer mediator during catalytic oxidation of NADH by diaphorase (Dp) at the anode of biofuel cell. PLL-VK3 and Dp were co-immobilized on an electrode and then coated with $\mathrm{NAD}(+)$-dependent glucose dehydrogenase (GDH). An oxidation current of $c a .2 \mathrm{~mA} \mathrm{~cm}$ was $^{-2}$ observed when the electrochemical cell contained a stirred $30 \mathrm{mM}$ glucose, $1.0 \mathrm{mM} \mathrm{NAD}(+), \mathrm{pH} 7.0$ phosphate-buffered electrolyte solution. The open circuit voltage of a glucose $/ \mathrm{O}_{2}$ biofuel cell with the PDMS-coated Pt cathode was $0.55 \mathrm{~V}$ and its maximum power density was $32 \mu \mathrm{W} \mathrm{cm}{ }^{-2}$ at $0.29 \mathrm{~V}$ when a pH 7.0 buffered fuel containing $5.0 \mathrm{mM}$ glucose and $1.0 \mathrm{mM} \mathrm{NAD(+)}$ was introduced into the cell at a flow rate of $1.0 \mathrm{~mL} \mathrm{~min}{ }^{-1}$. The cell's output current density declined by ca. $50 \%$ during $18 \mathrm{~h}$ operation [96].

Apart from glucose, other organic fuels such as alcohol and glycerol have been also used in enzymatic biofuel cells. An enzymatic biofuel cell using ethanol and operate at ambient temperature has been developed. The anode of the biofuel cell was based on immobilized quino-hemoprotein-alcohol dehydrogenase (QH-ADH), while the cathode on co-immobilized alcohol oxidase (AOx) and 
microperoxidase (MP-8). The enzymes are able to have direct electron transfer (DET) to the electrode surfaces. The maximal open circuit potential of the biofuel cell was $240 \mathrm{mV}$ [97].

Glycerol has attracted increasing interest because it is a by-product of biodiesel production. An enzymatic biofuel cell was developed by using glycerol as the fuel and employing a three-enzyme cascade on the anode that can accomplish the complete oxidation of glycerol [98]. The bioanode that was developed contained PQQ-ADH, PQQ-AldDH and oxalate oxidase immobilised within a tetrabutylammonium-modified Nafion membrane. The glycerol/air biofuel cell yielded power densities of up to $1.32 \mathrm{~mW} \mathrm{~cm}^{-2}$, and have the ability to operate at high fuel concentrations.

Nano carbon materials, such as carbon fibre and carbon nanotubes have been also applied in enzymatic biofuel cells because of their excellent electronic properties. A passive-type biofuel cell units, which generate a power over $100 \mathrm{~mW}$ with the volume of $80 \mathrm{~cm}^{3}$ operated at $\mathrm{pH} 7$. The maximum power density was accomplished of $c a .1 .45 \pm 0.24 \mathrm{~mW} \mathrm{~cm}^{-2}$ at $0.3 \mathrm{~V}$. This performance was achieved by densely packed enzymes and mediator on carbon-fiber electrodes with the enzymatic activity retained. The cell units with a multi-stacked structure successfully operate a radio-controlled car [99].

Membrane-less and mediator-free direct electron transfer enzymatic biofuel cells with bioelectrodes comprised of single wall carbon nanotubes (SWNTs) deposited on porous silicon substrates were reported. Anodic glucose oxidase (GOx) and cathodic laccase (Lac) were immobilized on the porous silicon/SWNT substrates used in the fuel cell in $\mathrm{pH} 7$ phosphate buffer solution. A peak power density of $1.38 \mu \mathrm{W} \mathrm{cm}{ }^{2}$ (with a lifetime of $24 \mathrm{~h}$ ) down to $0.3 \mu \mathrm{W} \mathrm{cm}{ }^{2}$ was obtained in $4 \mathrm{mM}$ glucose solution as fuel and air as oxidant [100]. Fuel cell performances are summarised in Table 1 (see next page).

\section{Conclusions and Outlook}

Rapid development on enzymatic biofuel cells has been achieved in the past decade. Much of the research has focused on establish efficient electronic communications and interactions between enzyme-electrode with various approaches. With the demands for reliable power supplies for medical devices for implantable applications, enzymatic biofuel cells has shown particular advantages over conventional energy devices because of the specific activity from enzymes and the capability of miniaturisation. In additional to medical applications, enzymatic biofuel cells can use renewable fuels with high energy density and safety for microelectronics. The technology developed on enzyme electrode fabrication has also stimulated the advances in biosensor applications.

However, there are great challenges hamper further advances in the technology. The most significant issues include: long term stability of the enzyme electrodes, efficient electron transfer between enzymes and electrode surfaces, and improved enzyme biocatalytic activity: for biofuel cells with increased power output. These are the main objectives for the next generation enzyme electrodes for biofuel cells. 
Table 1. Summary of enzymatic biofuel cell performances.

\begin{tabular}{|c|c|c|c|c|c|}
\hline Anode & Cathode & Open circuit voltage/mV & Short-circuit current & Power/power density & Ref. \\
\hline $\begin{array}{l}\text { PQQ monolayer- } \\
\text { functionalized-Au-electrode } \\
\text { Fuel: 1,4-dihydronicotinamide } \\
\text { adenine dinucleotide, NADH }\end{array}$ & $\begin{array}{l}\text { microperoxidase-11 } \\
\text { (MP-11)-modified } \\
\text { Au-electrode } \\
\text { Oxidant: } \mathrm{H}_{2} \mathrm{O}_{2}\end{array}$ & 320 & $30 \mu \mathrm{A} \mathrm{cm}{ }^{-2}$ & $8 \mu \mathrm{W}$ & {$[44]$} \\
\hline $\begin{array}{l}\text { reconstituted glucose oxidase } \\
\text { monolayer on gold } \\
\text { Fuel: glucose }\end{array}$ & $\begin{array}{l}\text { reconstituted cytochrome } \\
\text { c/cytochrome oxidase couple } \\
\text { Oxidant: } \mathrm{O}_{2}\end{array}$ & 130 & $\begin{array}{l}\text { transduced current } \\
\text { density at a glucose } \\
\text { concentration of } 80 \mathrm{mM} \\
\text { corresponds to } \\
\text { ca. } 200 \mu \mathrm{A} \mathrm{cm}\end{array}$ & $4 \mu \mathrm{W}$ & [93] \\
\hline Fuel: glucose & Oxidant: $\mathrm{O}_{2}$ & 120 & $550 \mu \mathrm{A} \mathrm{cm}^{-2}$ & $4.3 \mu \mathrm{W}$ & [94] \\
\hline $\begin{array}{l}\text { Os derivatives polymer } \\
\text { mediators } \\
\text { Fuel: glucose }\end{array}$ & $\begin{array}{l}\text { Os derivatives polymer } \\
\text { mediators } \\
\text { Oxidant: } \mathrm{O}_{2}\end{array}$ & 600 & & 4.8 IJ.W mm ${ }^{-2}$ & {$[82]$} \\
\hline $\begin{array}{l}\text { glucose oxidase and using } \\
1,1 \text { '-dicarboxyferrocene as } \\
\text { mediator } \\
\text { Fuel: fruit juices (orange, } \\
\text { banana and grape juice) }\end{array}$ & $\begin{array}{l}\text { Laccase and using } \\
1,1^{\prime} \text {-dicarboxyferrocene } \\
\text { as mediator } \\
\text { Oxidant: } \mathrm{O}_{2}\end{array}$ & $\begin{array}{l}220 \text { without mediator } \\
195 \text { with ferrocen mediator } \\
\text { Grape juice as fuel: } 191 \\
\text { Banana juice as fuel: } 202 \\
\text { Orange juice as fuel: } 360 \text { six } \\
\text { as-prepared BFCs by using } \\
\text { orange juice as fuels in series } \\
\text { have reached } V_{\text {oc }} \text { value of } 2.2 \mathrm{~V}\end{array}$ & $\begin{array}{l}109.8 \mu \mathrm{A} \mathrm{cm}^{-2} \text { with } \\
\text { glucose } \\
56 \mu \mathrm{A} \text { (current density } \\
c a .136 .6 \mu \mathrm{A} \mathrm{cm}^{-2} \text { ) } \\
60 \mu \mathrm{A}, \text { current density } \\
c a .146 .3 \mu \mathrm{A} \mathrm{cm}^{-2} \text { ) } \\
72 \mu \mathrm{A}, \text { current density } \\
c a .175 .6 \mu \mathrm{A} \mathrm{cm}^{-2} \text { ) }\end{array}$ & $\begin{array}{l}11.66 \mu \mathrm{W} \text { (power density } \\
\text { ca. } 28.4 \mu \mathrm{W} \mathrm{cm}^{-2} \text { ) }\end{array}$ & {$[9]$} \\
\hline
\end{tabular}


Table 1. Cont.

\begin{tabular}{|c|c|c|c|c|c|}
\hline Anode & Cathode & $\begin{array}{l}\text { Open circuit } \\
\text { voltage } / \mathbf{m V}\end{array}$ & $\begin{array}{c}\text { Short-circuit } \\
\text { current }\end{array}$ & Power/power density & Ref. \\
\hline $\begin{array}{l}\text { poly-L-lysine (PLL-VK3) as } \\
\text { mediator for diaphorase (Dp) } \\
\text { oxidation of NADH and then } \\
\text { coated with glucose dehydrogenase } \\
\text { Fuel: NADH and glucose }\end{array}$ & $\begin{array}{l}\text { PDMS-coated Pt } \\
\text { Oxidant: } \mathrm{O}_{2}\end{array}$ & 550 & $0.13 \mathrm{~mA} \mathrm{~cm}^{-2}$ & $\begin{array}{l}32 \mu \mathrm{W} \mathrm{cm} \text { at } 0.29 \mathrm{~V} \text { when a pH } 7.0 \\
\text { buffered fuel containing } 5.0 \mathrm{mM} \\
\text { glucose and } 1.0 \mathrm{mM} \mathrm{NAD(+)}\end{array}$ & {$[96]$} \\
\hline $\begin{array}{l}\text { PQQ-ADH, PQQ-AldDH and } \\
\text { oxalate oxidase immobilised within } \\
\text { a tetrabutylammonium-modified } \\
\text { Nafion membrane } \\
\text { Fuel: glycerol }\end{array}$ & Oxidant: $\mathrm{O}_{2}$ & & $\begin{array}{l}3.5 \pm 0.48 \mathrm{~mA} \mathrm{~cm}^{-2} \\
\text { with } 5 \mathrm{M} \text { glycerol }\end{array}$ & $1.32 \mathrm{~mW} \mathrm{~cm}^{-2}$ & [98] \\
\hline $\begin{array}{l}\text { Anodic glucose oxidase (GOx) } \\
\text { immobilized on the porous } \\
\text { silicon/SWNT substrates } \\
\text { Fuel: glucose }\end{array}$ & $\begin{array}{l}\text { cathodic laccase (Lac) } \\
\text { immobilized on the porous } \\
\text { silicon/SWNT substrates } \\
\text { Oxidant: Air/ } \mathrm{O}_{2}\end{array}$ & & $30 \mu \mathrm{A} \mathrm{cm}{ }^{-2}$ & $\begin{array}{l}1.38 \mu \mathrm{W} \mathrm{cm}{ }^{2} \text { down to } 0.3 \mu \mathrm{W} \mathrm{cm}{ }^{-2} \\
\text { in } 24 \mathrm{~h} \text { was obtained in } 4 \mathrm{mM} \\
\text { glucose solution }\end{array}$ & [100] \\
\hline
\end{tabular}


In order to overcome the challenges and achieve the goals, these areas are essential to push forward the technology for practical applications and commercialisation.

(1) Protein engineering to engineering native enzyme molecules with desired properties tailored for specific applications. There two main strategies in protein engineering are rational design, which combines site-directed mutagenesis with the detailed knowledge of enzyme structures and functions or computational models, and directed evolution, which is based on the random synthesis of a pool of mutated enzymes and the subsequent selection by an iterative process [101]. Mutant glucose oxidase obtained from directed evolution has shown improved $\mathrm{pH}$ and thermal stability. The biological catalytic kinetics and affinity between mutant enzyme and substrate were improved [21]. Moreover, electrochemical characterisation of mutant enzymes also showed improved electrochemical catalytic activity and electron transfer rate from the mutant glucose oxidase comparing to wild type enzyme [102].

(2) New immobilisation method and biomaterials to improve the stability of enzymes. Immobilisation of enzymes in hydrophilic sol-gel matrixes and ionic liquids has yielded desired stability and direct electron transfer from enzyme electrodes [103-107]. Biomaterials based on novel phospholipid polymers with unit imitating biomembrane have been developed. They have excellent biocompatibility and the ability of maintaining enzyme activity [20,108]. These new methods and materials provide new means in developing enzyme electrode with required stability.

(3) Nanomaterials integrated in the enzyme electrode structure to improve the electron transfer and enzyme catalytic activity. Gold nano particles and nano carbon materials have been utilised to establish and improve the electron transfer between enzyme active centre and electrodes because of their excellent electronic properties [100,109-111]. Mesoporous materials can be another substrate for enzyme immobilisation. The ordered porous structure with high surface area can increase the enzyme loading and improve the electrode activity.

(4) Novel design on fuel cell configuration to improve the cell voltage and power out put. For conventional fuel cells, fuel cell stacks are normally developed to achieve high cell voltage and power output. The same principles can be also applied to biofuel cells. Modular microfluidics makes it possible to develop miniaturised biofuel cell stacks with substantial power output.

Successful development of biofuel cell technology requires the joint efforts from different disciplines, biology to understand biomolecules, chemistry to gain knowledge on biochemical reaction and electron transfer mechanisms; material science to develop novel materials with high biocompatibility and maintaining activity from biomolecues and chemical engineering to design and establish the system. This innovative technology will encourage the energy production from renewable sources, and will make major impact and benefit for medical science and clinical research and healthcare management.

\section{Acknowledgements}

Eileen Yu thanks EPSRC for a research fellowship (EP/C535456/1) to carry out this work. 


\section{References}

1. Rigla, M.; Hernando, M.E.; Gomez, E.J.; Brugues, E.; Garcia-Saez, G.; Capel, I.; Pons, B.; de Leiva, A. Real-time continuous glucose monitoring together with telemedical assistance improves glycemic control and glucose stability in pump-treated patients. Diabetes Technol. Therapeut. 2008, 10, 194-199.

2. Heller, A. Implanted electrochemical glucose sensors for the management of diabetes. Annu. Rev. Biomed. Eng. 1999, 1, 153-175.

3. Barton, C.S.; Gallaway, J.; Atanassov, P. Enzymatic biofuel cells for implantable and microscale devices. Chem. Rev. 2004, 104, 4867-4886.

4. Heller, A.; Miniature biofuel cells. Phys. Chem. Chem. Phys. 2004, 6, 209-216.

5. Itamar, W. Biofuel cells: Harnessing biomass or body fluids for the generation of electrical power. Fuel Cells 2009, 9, 5.

6. Suwansa-Ard, S.; Kanatharana, P.; Asawatreratanakul, P.; Limsakul, C.; Wongkittisuksa, B.; Thavarungkul, P. Semi disposable reactor biosensors for detecting carbamate pesticides in water. Biosens. Bioelectron. 2005, 21, 445-454.

7. Tizzard, A.C.; Lloyd-Jones, G. Bacterial oxygenases: In vivo enzyme biosensors for organic pollutants. Biosens. Bioelectron. 2007, 22, 2400-2407.

8. Liu, L.J.; Chen, Z.C.; Yang, S.N.; Jin, X.; Lin, X.F.; A novel inhibition biosensor constructed by layer-by-layer technique based on biospecific affinity for the determination of sulfide. Sens. Actuators B: Chem. 2008, 129, 218-224.

9. Liu, Y.; Dong, S.J. A biofuel cell harvesting energy from glucose-air and fruit juice-air. Biosens. Bioelectron. 2007, 23, 593-597.

10. Cracknell, J.A.; Vincent, K.A.; Armstrong, F.A. Enzymes as working or inspirational electrocatalysts for fuel cells and electrolysis. Chem. Rev. 2008, 108, 2439-2461.

11. Ramanavicius, A.; Kausaite, A.; Ramanaviciene, A. Biofuel cell based on direct bioelectrocatalysis. Biosens. Bioelectron. 2005, 20, 1962-1967.

12. The bioeconomy at work: Sony develops most efficient biofuel cell ever, powered by sugar; Available online: http://news.mongabay.com/bioenergy/2007/08/bioeconomy-at-work-sonydevelops-most.html (accessed on 17 December 2009).

13. Yahiro, A.T.; Lee, S.M.; Kimble, D.O. Bioelectrochemistry: I. Enzyme utilizing bio-fuel cell studies. BBA-Biophys. 1964, 88, 375-383.

14. Rusling, J.F.; Ito, K. Voltammetric determination of electron-transfer rate between an enzyme and a mediator. Anal. Chim. Acta 1991, 252, 23-27.

15. Gallaway, J.W.; Calabrese Barton, S.A. Kinetics of redox polymer-mediated enzyme electrodes. J. Am. Chem. Soc. 2008, 130, 8527-8536.

16. Katz, E.; Lioubashevsky, O.; Willner, I. Electromechanics of a redox-active rotaxane in a monolayer assembly on an electrode. J. Am. Chem. Soc. 2004, 126, 15520-15532.

17. Ishihara, K.; Oshida, H.; Endo, Y.; Ueda, T.; Watanabe, A.; Nakabayashi, N. Hemocompatibility of human whole blood on polymers with a phospholipid polar group and its mechanism. J. Biomed. Mater. Res. 1992, 26, 1543-1552. 
18. Ishihara, K.; Iwasaki, Y.; Nakabayashi, N. Novel biomedical polymers for regulating serious biological reactions. Ma. Sci. Eng. C-Biomim. Supram. S. 1998, 6, 253-259.

19. Konno, T.; Watanabe, J.; Ishihara, K.; Conjugation of enzymes on polymer nanoparticles covered with phosphorylcholine groups. Biomacromolecules 2004, 5, 342-347.

20. Nishizawa, K.; Konno, T.; Takai, M.; Ishihara, K. Bioconjugated phospholipid polymer biointerface for enzyme-linked immunosorbent assay. Biomacromolecules 2008, 9, 403-407.

21. Zhu, M.W.; Gautam, A.; Nazor, J.; Momeu, C.; Prodanovic R.; Schwaneberg, U. Directed evolution of glucose oxidase from Aspergillus niger for ferrocenemethanol-mediated electron transfer. Biotechnol. J. 2007, 2, 241-248.

22. Yu, E.H.; Sundmacher, K. Enzyme electrodes for glucose oxidation prepared by electropolymerization of pyrrole. Process Saf. Environ. Prot. 2007, 85, 489-493.

23. Willner, I.; Blonder, R.; Katz, E.; Stocker, A.; Buckmann, A.F. Reconstitution of apo-glucose oxidase with a nitrospiropyran-modified FAD cofactor yields a photoswitchable biocatalyst for amperometric transduction of recorded optical signals. J. Am. Chem. Soc. 1996, 118, 5310-5311.

24. Xiao, Y.; Patolsky, F.; Katz, E.; Hainfeld, J.F.; Willner, I. "Plugging into enzymes": Nanowiring of redox enzymes by a gold nanoparticle. Science 2003, 299, 1877-1881.

25. Degani, Y.; Heller, A. Direct electrical communication between chemically modified enzymes and metal-electrodes .2. Methods for bonding electron-transfer relays to glucose-oxidase and damino-acid oxidase. J. Am. Chem. Soc. 1988, 110, 2615-2620.

26. Chen, Q.; de LumleyWoodyear, T.; Kenausis, G.; Schmidtke, D.; Heller, A. Developments in "wired" enzyme sensors. Abstr. Pap. Am. Chem. Soc. 1997, 213, 183-ANYL.

27. Zhu, Z.W.; Momeu, C.; Zakhartsev, M.; Schwaneberg, U. Making glucose oxidase fit for biofuel cell applications by directed protein evolution. Biosens. Bioelectron. 2006, 21, 2046-2051.

28. Gooding, J.J.; Mearns, F.; Yang, W.R.; Liu, J.Q. Self-assembled monolayers into the 21(st) century: Recent advances and applications. Electroanalysis 2003, 15, 81-96.

29. Dieter, T.; Rennebergb, R. Encapsulation of glucose oxidase microparticles within a nanoscale layer-by-layer film: immobilization and biosensor applications. Biosens. Bioelectron. 2003, 18, 1491-1499.

30. Kudo, H.; Yagi, T.; Chu, M.; Saito, H.; Morimoto, N.; Iwasaki, Y.; Akiyoshi, K.; Mitsubayashi, $\mathrm{K}$. Glucose sensor using a phospholipid polymer-based enzyme immobilization method. Anal. Bioanal. Chem. 2008, 391, 1269-1274.

31. Raitman, O.A.; Katz, E.; Buckmann, A.F.; Willner, I. Integration of polyaniline/poly(acrylic acid) films and redox enzymes on electrode supports: an in situ electrochemical/surface plasmon resonance study of the bioelectrocatalyzed oxidation of glucose or lactate in the integrated bioelectrocatalytic systems. J. Am. Chem. Soc. 2002, 124, 6487-6496.

32. Zhang, S.; Yang, W.; Niu, Y.; Sun, C. Multilayered construction of glucose oxidase on gold electrodes based on layer-by-layer covalent attachment. Anal. Chim. Acta 2004, 523, 209-217.

33. Gooding J.J.; Erokhin, P.; Losic, D.; Yang, W.; Policarpio, V.; Liu, J.; Ho, F.M.; Situmorang, M.; Hibbert, D.B.; Shapter, J.G. Parameters important in fabricating enzyme electrodes using self-assembled monolayers of alkanethiols. Anal. Sci. 2001, 17, 3.

34. Moehlenbrock, M.J.; Minteer, S.D. Extended lifetime biofuel cells. Chem. Soc. Rev. 2008, 37, 1188-1196. 
35. Cooney, M.J.; Svoboda, V.; Lau, C.; Martin, G.; Minteer, S.D. Enzyme catalysed biofuel cells. Energy Environ. Sci. 2008, 1, 320-337.

36. Woodward, J.; Mattingly, S.M.; Danson, M.; Hough, D.; Ward, N.; Adams, M. In vitro hydrogen production by glucose dehydrogenase and hydrogenase. Nat. Biotechnol. 1996, 14, 872-874.

37. Mertens, R.; Liese, A. Biotechnological applications of hydrogenases. Curr. Opin. Biotechnol. 2004, 15, 343-348.

38. Heller, A. Electrical connection of enzyme redox centers to electrodes. J. Phys. Chem. 1992, 96, 3579-3587.

39. Bullen, R.A.; Arnot, T.C.; Lakeman, J.B.; Walsh, F.C. Biofuel cells and their development. Biosens. Bioelectron. 2006, 21, 2015-2045.

40. Katz, E.; Shipway, A.N.; Willner, I. Handbook of Fuel Cells, Vielstich, W.; Gasteriger, H.A.; Lamm, A., Eds.; John Wiley and Sons, Ltd.: London, UK, 2003.

41. Degani, Y.; Heller, A. Direct electrical communication between chemically modified enzymes and metal-electrodes .1. electron-transfer from glucose-oxidase to metal-electrodes via electron relays, bound covalently to the enzyme. J. Phys. Chem. 1987, 91, 1285-1289.

42. Schumacher, D.; Vogel, J.; Lerche, U. Construction and applications of an enzyme electrode for determination of galactose and galactose-containing saccharides. Biosens. Bioelectron. 1994, 9, 85-90.

43. Vincent, K.A.; Cracknell, J.A.; Lenz, O.; Zebger, I.; Friedrich, B.; Armstrong, F.A. Electrocatalytic hydrogen oxidation by an enzyme at high carbon monoxide or oxygen levels. Proc. Nat. Acad. Sci. USA 2005, 102, 16951-16954.

44. Willner, I.; Arad, G.; Katz, E. A biofuel cell based on pyrroloquinoline quinone and microperoxidase-11 monolayer-functionalized electrodes. Bioelectrochem. Bioenerget. 1998, 44, 209-214.

45. Willner, I.; HelegShabtai, V.; Blonder, R.; Katz, E.; Tao, G.L. Electrical wiring of glucose oxidase by reconstitution of FAD-modified monolayers assembled onto Au-electrodes. J. Am. Chem. Soc. 1996, 118, 10321-10322.

46. Katz, E.; Riklin, A.; Heleg-Shabtai, V.; Willner, I.; Buckmann, A.F. Glucose oxidase electrodes via reconstitution of the apo-enzyme: tailoring of novel glucose biosensors. Anal. Chim. Acta 1999, 385, 45-58.

47. Willner, V.; Blonder, R.; Katz, E.; Tao, G.; Buckmann, A.F.; Heller, A. Electrical Wiring of Glucose Oxidase by Reconstitution of FAD-Modified Monolayers Assembled onto Au-Electrodes. J. Am. Chem. Soc. 1996, 118, 10321.

48. Li, D.; Zhang, Y.; Li, J. Electrochemical study of 4-ferrocene thiophenol monolayers assembled on gold nanoparticles. Microelectron. Eng. 2003, 66, 91-94.

49. Kawaguchi, T.; Tada, K.; Shimazu, K. Redox and mass transport characteristics of domain-free mixed ferrocenyloctanethiol/alkanethiol monolayers on gold. J. Electroanal. Chem. 2003, 543, 41-49.

50. Felgenhauer, T.; Rong, H.T.; Buck, M. Electrochemical and exchange studies of self-assembled monolayers of biphenyl based thiols on gold. J. Electroanal. Chem. 2003, 550-551, 309-319. 
51. Schlereth, D.D.; Kooyman, R.P.H.; Self-assembled monolayers with biospecific affinity for lactate dehydrogenase for the electroenzymatic oxidation of lactate. J. Electroanal. Chem. 1997, 431, 285-295.

52. Sato, Y.; Mizutani, F. Electrochemical responses of cytochrome $\mathrm{c}$ on a gold electrode modified with mixed monolayers of 3-mercaptopropionic acid and n-alkanethiol. J. Electroanal. Chem. 1997, 438, 99-104.

53. Dong, S.; Li, J. Self-assembled monolayers of thiols on gold electrodes for bioelectrochemistry and biosensors. Bioelectrochem. Bioenerg. 1997, 42, 7-13.

54. Krysinski, P.; Brzostowska-Smolska, M. Capacitance characteristics of self-assembled monolayers on gold electrode. Bioelectrochem. Bioenerg. 1998, 44, 163-168.

55. Bourdillon, C.; Demaille, C.; Moiroux, J.; Saveant, J.M. Step-by-step immunological construction of a fully active multilayer enzyme electrode. J. Am. Chem. Soc. 1994, 116, 10328-10329.

56. Shoham, B.; Migron, Y.; Riklin, A.; Willner, I.; Tartakovsky, B. A bilirubin biosensor based on a multilayer network enzyme electrode. Biosens. Bioelectron. 1995, 10, 341-352.

57. Lowy, D.A.; Finklea, H.O. Gold electrodes with polyion multilayers and electrostatically bound redox couples. Electrochim. Acta 1997, 42, 1325-1335.

58. Yoon, H.C.; Kim, H.S.; Multilayered assembly of dendrimers with enzymes on gold: Thickness-controlled biosensing interface. Anal. Chem. 2000, 72, 922-926.

59. Calvo, E.J.; Battaglini, F.; Danilowicz, C.; Wolosiuk, A.; Otero, M. Layer-by-layer electrostatic deposition of biomolecules on surfaces for molecular recognition, redox mediation and signal generation. Faraday Discussions 2000, 116, 47-65.

60. Ramanavicius, A.; Ramanaviciene, A.; Malinauskas, A. Electrochemical sensors based on conducting polymer- polypyrrole. Electrochim. Acta 2006, 51, 6025-6037.

61. Sung, W.J.; Bae, Y.H. A Glucose Oxidase Electrode Based on Electropolymerized Conducting Polymer with Polyanion-Enzyme Conjugated Dopant. Anal. Chem. 2000, 72, 2177-2181.

62. Serge, C.G.; Watelet, J.C. A Polypyrrole-bienzyme electrode (salicylate hydroxylase-polyphenol oxidase) for the interference-free determination of salicylate. Electroanalysis 2001, 13, 906-910.

63. Yasuzawa, M.; Nieda, T.; Hirano, T.; Kunugi, A. Properties of glucose sensors based on the immobilization of glucose oxidase in N-substituted polypyrrole film. Sens. Actuators B: Chem. 2000, 66, 77-79.

64. Gondran, C.; Cosnier; S. Fabrication of biosensors by attachment of biological macromolecules to electropolymerized conducting films. Analusis 1999, 27, 558.

65. Cosnier, S.; Senillou, A.; Gratzel, M.; Comte, P.; Vlachopoulos, N.; Jaffrezic Renault, N.; Martelet, C. A glucose biosensor based on enzyme entrapment within polypyrrole films electrodeposited on mesoporous titanium dioxide. J. Electroanal. Chem. 1999, 469, 176-181.

66. Trojanowicz, M.; Matuszewski, W.; Podsiadla, M. Enzyme entrapped polypyrrole modified electrode for flow-injection determination of glucose. Biosens. Bioelectron. 1990, 5, 149-156.

67. Cosnier, S.; Deronzier, A.; Roland, J.F. Electrocatlatic oxidation of alcohols on carbon electrodes modified by functionalised polypyrrole RuO2 films. J. Molecular Cata. 1992, 71, 303-315.

68. Cosnier, S. Fabrication of amperometric biosensors by entrapment of enzymes in functionalized polypyrrole films. Can. J. Chem. Eng. 1998, 76, 1000-1007. 
69. Cosnier, S.; Stoytcheva, M.; Senillou, A.; Perrot, H.; Furriel, R.P.M.; Leone, F.A. A biotinylated conducting polypyrrole for the spatially controlled construction of an amperometric biosensor. Anal. Chem. 1999, 71, 3692-3697.

70. Ouerghi, C.; Touhami, A.; Jaffrezic-Renault, N.; Martelet, C.; Ben Ouada, H.; Cosnier, S. Electrodeposited biotinylated polypyrrole as an immobilization method for impedimetric immunosensors. IEEE Sens. J. 2004, 4, 559-567.

71. Cooper, J.C.; Hall, E.H. Catalytic Reduction of Benzoquinone at Polyaniline and Polyaniline Enzyme Films. Electroanalysis 1993, 5, 385-397.

72. Raitman, O.E.; Buckmann, A.F.; Willner, I.; Integration of polyaniline/poly(acrylic acid) films and redox enzymes on electrode supports: An in situ electrochemical/surface plasmon resonance study of the bioelectrocatalyzed oxidation of glucose or lactate in the integrated bioelectrocatalytic systems. J. Am. Chem. Soc. 2002, 124, 6487.

73. Xue, H.G.; Shen, Z.Q.; Li, C.M.; Improved selectivity and stability of glucose biosensor based on in situ electropolymerized polyaniline-polyacrylonitrile composite film. Biosens. Bioelectron. 2005, 20, 2330-2334.

74. Raitman, O.A.; Patolsky, F.; Katz, E.; Willner, I. Electrical contacting of glucose dehydrogenase by the reconstitution of a pyrroloquinoline quinone-functionalized polyaniline film associated with an Au-electrode: an in situ electrochemical SPR study. Chem. Commun. 2002, 8,1936-1937.

75. Shi, L.X.; Xiao, Y.; Willner, I. Electrical contacting of glucose oxidase by DNA-templated polyaniline wires on surfaces. Electrochem. Commun. 2004, 6, 1057-1060.

76. Gregg, B.A.; Heller, A. Redox polymer-films containing enzymes .2. glucose-oxidase containing enzyme electrodes. J. Phys. Chem. 1991, 95, 5976-5980.

77. Gregg, B.A.; Heller, A. Redox polymer-films containing enzymes .1. A redox-conducting epoxy cement-synthesis, characterization, and electrocatalytic oxidation of hydroquinone. J. Phys. Chem. 1991, 95, 5970-5975.

78. Barton, S.C.; Kim, H.H.; Binyamin, G.; Zhang, Y.C.; Heller, A. The "wired" laccase cathode: High current density electroreduction of $\mathrm{O}-2$ to water at $+0.7 \mathrm{~V}$ (NHE) at pH 5. J. Am. Chem. Soc. 2001, 123, 5802-5803.

79. Barton, S.C.; Kim, H.H.; Binyamin, G.; Zhang, Y.C.; Heller, A. Electroreduction of O-2 to water on the "Wired" laccase cathode. J. Phys. Chem. B 2001, 105, 11917-11921.

80. Kang, C.; Shin, H.; Heller, A. On the stability of the "wired" bilirubin oxidase oxygen cathode in serum. Bioelectrochemistry 2006, 68, 22-26.

81. Soukharev, V.; Mano, N.; Heller, A. A four-electron O-2-electroreduction biocatalyst superior to platinum and a biofuel cell operating at 0.88 V. J. Am. Chem. Soc. 2004, 126, 8368-8369.

82. Mano, N.; Mao, F.; Heller, A. A miniature membrane-less biofuel cell operating at $+0.60 \mathrm{~V}$ under physiological conditions. Chembiochemistry 2004, 5, 1703-1705.

83. Kim, H.H.; Zhang, Y.C.; Heller, A. Bilirubin oxidase label for an enzyme-linked affinity assay with O-2 as substrate in a neutral $\mathrm{pH} \mathrm{NaCl}$ solution. Anal. Chem. 2004, 76, 2411-2414.

84. Mano, N.; Mao, F.; Shin, W.; Chen, T.; Heller, A. A miniature biofuel cell operating at 0.78 V. Chem. Commun. 2003, 7, 518-519. 
85. Mano, N.; Fernandez, J.L.; Kim, Y.; Shin, W.; Bard, A.J.; Heller, A. Oxygen is electroreduced to water on a "wired" enzyme electrode at a lesser overpotential than on platinum. J. Am. Chem. Soc. 2003, 125, 15290-15291.

86. Mano, N., Kim, H.H.; Zhang, Y.C.; Heller, A. An oxygen cathode operating in a physiological solution. J. Am. Chem. Soc. 2002, 124, 6480-6486.

87. Barton, S.C.; Pickard, M.; Vazquez-Duhalt, R.; Heller, A. Electroreduction of O-2 to water at 0.6 $\mathrm{V}(\mathrm{SHE})$ at $\mathrm{pH} 7$ on the 'wired' Pleurotus ostreatus laccase cathode. Biosens. Bioelectron. 2002, 17, 1071-1074.

88. Pishko, M.V.; Michael, A.C.; Heller, A. Amperometric glucose microelectrodes prepared through immobilisation of glucose-oxidase in redox hydrogels. Anal. Chem. 1991, 63, 2268-2272.

89. Chen, T.; Barton, S.C.; Binyamin, G.; Gao, Z.Q.; Zhang, Y.C.; Kim, H.H.; Heller, A. A miniature biofuel cell. J. Am. Chem. Soc. 2001, 123, 8630-8631.

90. Nakabayashi, N.; Williams, D.F. Preparation of non-thrombogenic materials using 2-methacryloyloxyethyl phosphorylcholine. Biomaterials 2003, 24, 2431-2435.

91. Yu, E.; Himuro, Y.; Takai, M.; Ishihara, K. Feasibility study of introducing redox property by modification of PMBN polymer for biofuel cell applications. Appl. Biochem. Biotech. 2009, DOI: 10.1007/s12010-009-8664-2.

92. Himuro, Y.; Takai, M.; Ishihara, K. Poly(vinylferrocene-co-2-hydroxyethyl methacrylate) mediator as immobilized enzyme membrane for the fabrication of amperometric glucose sensor. Sens. Actuators B: Chem. 2009, 136, 122-127.

93. Katz, E.; Willner, I.; Kotlyar, A.B. A non-compartmentalized glucose/O2 biofuel cell by bioengineered electrode surfaces. J. Electroanal. Chem. 1999, 479, 64-68.

94. Katz, E.; Willner, I. A biofuel cell with electrochemically switchable and tunable power output. $J$. Am. Chem. Soc. 2003, 125, 6803-6813.

95. Amir, L.; Tam, T.K.; Pita, M.; Meijler, M.M.; Alfonta, L.; Katz, E. Biofuel cell controlled by enzyme logic systems. J. Am. Chem. Soc. 2009, 131, 826-832.

96. Togo, M.; Takamura, A.; Asai, T.; Kaji, H.; Nishizawa, M. An enzyme-based microfluidic biofuel cell using vitamin K-3-mediated glucose oxidation. Electrochim. Acta 2007, 52, 46694674.

97. Ramanavicius, A.; Kausaite, A.; Ramanaviciene, A. Enzymatic biofuel cell based on anode and cathode powered by ethanol. Biosens. Bioelectron. 2008, 24, 761-766.

98. Arechederra, R.L.; Minteer, S.D. Complete oxidation of glycerol in an enzymatic biofuel cell. Fuel Cells 2009, 9, 63-69.

99. Sakai, H.; Nakagawa, T.; Tokita, Y.; Hatazawa, T.; Ikeda, T.; Tsujimura, S.; Kano, K. A high-power glucose/oxygen biofuel cell operating under quiescent conditions. Energy Environ. Sci. 2009, 2, 133-138.

100. Wang, S.C.; Yang, F.; Silva, M.; Zarow, A.; Wang, Y.B.; Iqbal, Z. Membrane-less and mediator-free enzymatic biofuel cell using carbon nanotube/porous silicon electrodes. Electrochem. Commun. 2009, 11, 34-37.

101. Wong, T.S.; Schwaneberg, U. Protein engineering in bioelectrocatalysis. Curr. Opin. Biotechnol. 2003, 14, 590-596. 
102. Yu, E.H.; Ostafe R.; Schwaneberg, U. Electrochemical oxidation of glucose using mutant glucose oxidase from directed protein evolution. In Proceedings of the 214th ECS Meeting. Honolulu, HI, USA, October, 2008.

103. Kandimalla, V.B.; Tripathi, V.S.; Ju, H.X. Immobilization of biomolecules in sol-gels: Biological and analytical applications. Cri. Rev. Anal. Chem. 2006, 36, 73-106.

104. Pierre, A.C. The sol-gel encapsulation of enzymes. Biocatal. Biotrans. 2004, 22, 145-170.

105. Xiang, C.L.; Zou, Y.J.; Sun, L.X.; Xu, F. Direct electron transfer of cytochrome c and its biosensor based on gold nanoparticles/room temperature ionic liquid/carbon nanotubes composite film. Electrochem. Commun. 2008, 10, 38-41.

106. Wei, D.; Ivaska, A. Applications of ionic liquids in electrochemical sensors. Anal. Chim. Acta 2008, 607, 126-135.

107. Pauliukaite, R.; Doherty, A.P.; Murnaghan, K.D.; Brett, C.M.A. Characterisation and application of carbon film electrodes in room temperature ionic liquid media. J. Electroanal. Chem. 2008, $616,14-26$.

108. Goto, Y.; Matsuno, R.; Konno, T.; Takai, M.; Ishihara, K. Polymer nanoparticles covered with phosphorylcholine groups and immobilized with antibody for high-affinity separation of proteins. Biomacromolecules 2008, 9, 828-833.

109. Tan, Y.M.; Deng, W.F.; Ge, B.; Xie, Q.J.; Huang, J.H.; Yao, S.Z. Biofuel cell and phenolic biosensor based on acid-resistant laccase-glutaraldehyde functionalized chitosan-multiwalled carbon nanotubes nanocomposite film. Biosens. Bioelectron. 2009, 24, 2225-2231.

110. Mani, V.; Chikkaveeraiah, B.V.; Patel, V.; Gutkind, J.S.; Rusling, J.F. Ultrasensitive immunosensor for cancer biomarker proteins using gold nanoparticle film electrodes and multienzyme-particle amplification. ACS Nano 2009, 3, 585-594.

111. Pingarron, J.M.; Yanez-Sedeno, P.; Gonzalez-Cortes, A. Gold nanoparticle-based electrochemical biosensors. Electrochim. Acta 2008, 53, 5848-5866.

(C) 2010 by the authors; licensee Molecular Diversity Preservation International, Basel, Switzerland. This article is an open-access article distributed under the terms and conditions of the Creative Commons Attribution license (http://creativecommons.org/licenses/by/3.0/). 